\title{
Reflections and challenges
}

\author{
Frances Awcock AM
}

\section{Introduction}

This paper draws on my own experience over what seems a lifetime and tries to draw on what I have learned along the way, some reflections on what I understand of the present and some implications for the future for libraries. Its focus is on my experience in libraries rather than on the profession itself.

In some ways my own career has been less about the profession of librarianship than it has about that which has given rise to our profession - libraries as entities in themselves. The very practice of librarianship is deeply influenced by the changing nature of the world around us and always has been. It is the momentum of change in the last two decades in particular that has deeply influenced me and had perhaps its greatest import for libraries and those of us who have made them not only our business but our life's work and passion.

Everything I say in this paper is predicated on one overarching principle, namely that our libraries are for the people we serve.

\section{Setting the scene}

My purpose today, is to challenge and stimulate you. It is not enough, however, to focus on the personal even though I have been asked to reflect on my career experience. Any observations I make will be designed to paint a broader picture as you, my audience, plan your own work, your libraries and your careers in the years ahead. Our real work should be to engage the uninitiated - those to whom our libraries have so far proved either irrelevant or wanting.

I first want to show you how things have certainly improved over the last century and continue to improve! I will quote you an excerpt from The Bulletin from the $1^{\text {st }}$ of March 1917 - that is 70 years before my 1987 conference presentation to this conference and 90 years ago from now - 2007. Those 3 dates $-1917,1987$ and 2007 have helped me construct this presentation. Remember that 1917 was at the time of the First World War and that obviously had influenced The Bulletin writer. Doubtless the quotation will either leave you
Fran Awcock, AM, has served in South Australia as the State Librarian and Director of the State Library and in Victoria as Chief Executive Officer of the State Library of Victoria and State Librarian 
speechless from your $21^{\text {st }}$ century perspective, or at least cause you to smile wryly if you recognize any similarity with any of your own experiences of libraries and librarianship.

For various reasons, the elderly fathers of the Melbourne Public Library do not employ women except to scrub floors. There are a good many jobs at the Library. It is a nice, cool, quiet spot in the summer time, and a sheltered and pleasant place without draughts in the winter. Much of the work consists in sitting down and waiting for somebody to turn up and ask for something; and a woman could almost do that. The time seems right to give her the chance. In neither war nor peace can we any longer afford to waste men in unproductive jobs. If the new arrivals at the library are nice things in clean pinnies and with a cheerful appearance, so much the better - always providing that the supply of disabled soldiers has failed to satisfy the demand.

Firstly, that type of attitude to work is outside my professional experience, thanks largely to the women around the world who strived for most of the second half of the $20^{\text {th }}$ century in particular to challenge and alter the almost universal, stereotypical view of women as being persons only suited to domestic and parental roles. I should hasten to add that I have always valued those roles - and also fulfilled them - but have not regarded them as exclusively female roles - and certainly not roles to preclude a working life of one's own.

Secondly, libraries are not usually quiet, restful places where staff wait patiently for someone to "turn up and ask for something"!! Any of you who has visited your own university, college, public or state library will have experienced the energy and bustle characteristic of the modern public library - a popular meeting place, study centre, discussion and reading venue where one may engage with the virtual world through use of the internet, or talk to like-minded persons or debate your differences with others, view films, play music or simply browse the shelves, sit, read and study. Your own theological libraries may be different in kind yet I am confident you do not spend your time waiting for someone to turn up and ask you for something!

Now let me read you something else surprisingly it is a prayer:

Lord, we thank you for the gift of language and for the written word. We thank you for writers, publishers and printers, for books and libraries, and for the spread of knowledge and the sharing of experience which comes to us through the printed page. We thank you for the books which have helped to shape our lives and to mould our tastes and values; they have furnished our minds, spoken to our hearts, enriched or entertained us, both in health and sickness. Teach us to value literacy and to use it rightly.

That prayer was included in May this year - that is, in 2007 - in a memorial service in Sydney honouring my former school Headmistress. I had been asked to speak at the service. In 35 years of practicing librarianship, apart from the many times I have been called on to talk about my work to various constituencies and at library conferences, I had never found myself in a position, where an audience or, in this case, a congregation of 200 people, none of whom were librarians or information professionals, had been invited so openly and clearly to acknowledge the role of libraries and all that underpins them. The contrast between the patronising words of 1917 and those spoken 90 years later in 2007 in that prayer could not be greater. I felt as though all I had worked for in my career had been well and truly vindicated. For to me, the written word in all its manifestations is paramount. That includes its role in all the new information and 
communication technologies as well as in its traditional forms - books, magazines, journals, newspapers, etc.

\section{Essentials of library practice}

This leads me to four key areas that I believe are essential to fibrary practice and its effectiveness. They form the substance of this paper and are:

1. a philosophical base, with all that implies

2. the buildings in which our libraries are housed

3. use of available technology to provide and enhance service.

4. financial, corporate and philanthropic support

\section{A philosophical base}

There are several components to this base. As I see them they are

- Communication

- Reading and Literacy

- Commitment to democracy and democratic service

- Library Co-operation

\subsection{Communication}

I recall saying in my 1987 presentation to your erstwhile colleagues, on whose work you are presumably building, that a librarian's key role will be as a facilitator of access to recorded knowledge - in other words his/her role will be one which facilitates communication. It is now my view that communication is our core role, not that it will be. Whatever means we use, whether it is at the one-on-one personal interactive level or by means of the latest information and communication technologies, it is a fundamental requirement that we choose and use the method and the means that best matches the need of that particular user at that particular time. It may even demand empathy of us rather than a purely matterof-fact approach. The latter is often only part of the transactional requirement. For what we surely seek is not only a satisfied user but one who will return without hesitation because of the confidence you have instilled in them.

The needs of our readers require us to review and re-order our services or to rethink the way we do things. It may also mean what in a department store is calied "floor walking" where the customer's need is either anticipated or sought before any move towards a kiosk or information point.

How often have we in libraries been dominated by reference desks and rosters which assume that our readers/users are confident enough either to make that initial enquiry or to understand our requirements of them? Many libraries have recognized these dilemmas and, while not dispensing with information or reference desks have staff also walking the floor where an informal encounter can often lead to a more confident and better satisfied user and a more discerning librarian.

Unfortunately communication is often also the means of our undoing. How many of us have failed to reach our target audience simply because we have not understood the individual or corporate need to know, or not recognized how best to impart the sought-for information? How often have we in our libraries rostered and depended on people charged with delivering information services without the requisite interpersonal skills? How many users have we "lost" as a result?

Modern notions of "Information literacy" have focused on the need for our users to be not only literate in the usual sense but able to engage with the latest information and communications technologies in ways that they find useful - and perhaps even transforming. Are we as a profession widely known and respected for our transformational 
powers or at least for guiding our users so they can harness relevant techniques or sources or find the right match between need and its satisfaction?

To achieve this, as a librarian are you and I not charged with a duty to be the epitome of a good communicator? Are we not charged with a duty to show the how as well as the what? It is how we engage our users that matters at least as much as what we provide or find or show them. I will return to this point later. Modern marketing know-how is predicated on understanding the customer and his/her needs. Any good librarian knows this and puts into practice appropriate strategies to demonstrate that understanding. This often means working alongside the person.

\subsection{Reading and Literacy}

The big question for me has been "Are libraries only about providing information or access to it?" My answer is a resounding "NO". For if information access is their sole purpose, we may as well surrender all to Google and its ilk.

Reading has always been fundamental to our purpose, from the earliest libraries to those of today. Universal literacy remains a United Nations Goal yet in 2007 unacceptable millions remain illiterate.

Between my role in the 1980 s as Director of Technical Services at the State Library of Victoria and then as Director and State Librarian of the State Library of South Australia in the 1990s, I spent 2 years as Executive Director of the now defunct National Book Council. Primarily this was because of my commitment to books and reading. It was also because I believed that our readers are better served if librarians engage with writers, publishers and booksellers.

My experience tells me that all too often the links in the chain of creation, production, distribution, access and interpretation are broken. This applies as much, if not more so, to the online world of today with its infinite complexities and possibilities whereby we can at one and the same time be the author, the creator, the publisher, the distributor.

As librarians we not only need to foster and understand these links but to read as widely as we can. This must surely make us more effective and provide a richer resource on which we can draw, even if subliminally. Although we cannot possibly cover all bases nor read any but an infinitesimally small number of books, articles, papers, etc. we can make an effort. All this is to describe an essential philosophical underpinning of my professional practice, namely the universal importance of reading. If we don't, who will or how can we espouse its efficacy?

\subsection{Commitment to democratic service}

Libraries are testament to the need to know, to our right to be educated and wellinformed, to be stimulated in our thinking and creativity. They are also testament to our obligations as citizens in a democracy where multiple perspectives, diverse cultures, languages and religious belief are allowed to be studied, challenged, discussed, expressed and celebrated. Note that I have mentioned the word "democracy". It is not for me to say how libraries in non-democratic nations should function but I know that my own cultural bias is governed by my background as an Australian citizen with all the rights and responsibilities that implies. Yet in today's world I must ask of myself and of you:

At what stage does the personal become the political?

Perhaps it is not only governments that must concern themselves with functioning in a world where millions have no 
experience of democracy and, were they to be given a choice, may well NOT choose democracy but what is already familiar to them. As librarians steeped in democratic traditions it is hard to accept that information in non-democratic states is either censored or deliberately made unavailable. We know how all pervasive the internet is and how government attempts to block access to it is counterproductive and doomed to failure in the longer term. The freedom to read is by no means a universally agreed principle even if we think it should be. So, from this angle it seems to me that much of our future as librarians will move from the personal to become the political.

Whereas our roles as librarians are firmly rooted in democracy, others are not. We may not engage in international politics but if any of you has any international experience through IFLA, for example, you will understand my point. In the year 2000 , for example, IFLA was held in Jerusalem. The decision to meet there resulted in a boycott by most Islamic countries. Had Tel Aviv, the political rather than the religious capital of Israel, been the venue, there would have been more support from those nations who were thus unrepresented at the conference. Even when differing political or religious systems meet around or across a table, there is no guarantee of uniform agreement. What can or ought we do to build bridges among our own libraries and those of other nations or should we even try? In my own experience the key means is through my fourth philosophical underpinning:

\subsection{Library Cooperation}

Our profession of librarianship has as one of its outstanding features the concept and practice of cooperation. Many of our systems are built on it, whether it is reciprocal borrowing, or interlibrary lending or enabling access to another library's collections and services. Today, it is an essential feature of our library services, with collections increasingly digitized for online access, services and programs identified, promoted and offered online, virtual tours of library buildings and much, much more.

A little history at this stage may be helpful, as a reminder of how far we have come. As early as the $1960 \mathrm{~s}$, fledgling efforts were made by the National Library of Australia to engage with both the USA and the UK through the exchange of catalogue data.

When I addressed this conference two decades after that - ie. 20 years ago from today, the Australian Bibliographic Network $(A B N)$ was at the bibliographic forefront of librarianship in Australia, drawing as it did on bibliographic records from the Library of Congress and the British Library as well as from our own National Library and indirectly from all those libraries who were contributing bibliographic data to a national database.

The National Library of Australia's visionaries foresaw, in their seminal report of 1980 , the day when libraries would not only be able to down load data but to upload it through contribution of unique records. Its current evolutionary form is Libraries Australia. Today, anyone using the internet can gain access to the collections of countless libraries here and elsewhere. Picture Australia is another example of Australian library cooperation with its online access to countless images held in several library and other collections.

A further example of library cooperation is Inter-country agreements or Memoranda of Understanding. These may be for access to each other's collections, the sharing of specified services and expertise or "know-how" or with staff placements or exchange programs.

I was honoured to have been able to initiate and sign such an agreement between the 
National Library Board of Singapore and the Library Board of Victoria several years ago and was delighted to read that it has recently been re-negotiated and renewed. The concept of the "library without borders" is one that will and must surely gather momentum, spurred on by the online world.

So, with these four elements as a philosophical basis for our workcommunication, reading and literacy, commitment to democracy and democratic service and library co-operation, I come now to the second of my "essentials of library practice" and what I regard as critical to a library's success and its place in the community it serves:

\section{Library buildings}

I will focus on:

- Transformation

- Glass as metaphor for access

- the Library as department store

- Furniture and furnishings

I will also take the liberty of talking briefly about two recent building projects with which I have been engaged.

For much of my career I have been deeply engaged with library buildings. From assisting with the planning for a new library/resource centre at what was then the State College of Victoria, Toorak in the 1970 s; to working in a dysfunctional set of buildings at the State Library of Victoria in the 1980s and helping document its inadequacies as the momentum for its restoration began; to agitating and "politicking" for a new or restored and extended State Library of South Australia for most of the 1990s and then to be deeply engaged at the State Library of Victoria in the late 1990s until I retired at the end of 2002 , in creating the vision for that great Library, and, with its architects Ancher, Mortlock and Woolley, mapping and masterminding the realization of that vision through transforming the buildings for specified purposes.

The process is not yet complete but much has been achieved as my successor AnneMarie Schwirtlich continues to drive the Library's transformation in all its guises. As at 2007, it has to be THE most impressive library site in the nation, although I admit my bias.

\subsection{Transformation from Old to New}

It is true to say that all building, whether it be re-furbishment and renovation or new construction, is intended to be a transformation either from one state to another or from nothing to something. I like to think of this transformation as it applies to libraries as not only physical, but metaphysical, breathing new life and purpose into our systems and services, and psychological whereby our users' experience of the new building or facilities embeds in their thinking the importance of the library as an institution in our society. I know that in the State Libraries of South Australia and Victoria the transformation of the buildings has given rise to new forms and levels of use, increased public support and widespread acknowledgment of their role.

Libraries have nearly always been readily identifiable within their local community, whether it be in the suburb, town, city, university, college or school. The library building usually has a high recognition level partly due to its role as a community hub and also because of the services it offers. In today's world libraries are being transformed by new forms of building, where new functions require new forms, readily adaptable to changing information and communication technologies, as well as to changing community expectations and use.

\subsection{Glass as a metaphor for access}

It is not by chance that modern libraries have, as a distinguishing feature, a significant amount of glass as part of their 
construction. Although scholarly libraries across the centuries have been characterized by denser building forms, with light seen more as a destructive rather than an enabling force, today even the scholarly library finds new ways of protecting precious collections yet providing their users with surroundings that are comfortable and welcoming.

In my mind the State Library of Victoria, as with many nineteenth century libraries, was always associated with density - the walls of its many buildings seemed impenetrable, the glass in what was known as the Domed Reading Room had been removed with consequent loss of light and each building seemed disconnected from the other. Such density seemed to me to speak of services and collections that were hard to use or to access. Re-instatement of the glass in the Dome of what is now the LaTrobe Reading Room has transformed that space. Similarly the cleaning and restoration of what was once a dense museum exhibition hall has resulted in its transformation into the Redmond Barry Reading Room with its marvelous use of natural lighting through the original skylights.

Similarly, replacement of brick and plaster walls with glass walls and doors and creation of external spaces to become new interior spaces with glass ceilings has certainly transformed the Library. Now you can see into places more easily. They have become more inviting and the Library's users certainly enjoy them if growing use and demand is any indicator.

\subsection{Library as Department Store}

A modern public library trend has been to convey through the buildings themselves something akin to the modern department store - multi level, with escalators, elevators and stairs. It also applies to the display of stock or, in our case, collections and to signage. I can think of the Rotterdam Public
Library and the Vancouver Public Library as notable examples of this feature.

While many library buildings have themselves become architectural icons and in so doing, conveyed distinction on the library itself and brought new attention to them, it is their purpose we need to keep at the forefront of our thinking.

Obviously not all libraries will become iconic as buildings but we as librarians need to work to ensure that our services become iconic, in the sense that others will say of them: "here is the library that is the best of its kind. Its staff is welcoming; they are responsive and receptive; they engage in new thinking about how best to meet my needs; they are at the forefront in terms of using the most effective tools at their disposal. Information and communications technologies are used wisely and creatively to assist me. They do so regardless of my background or status or whether my need is simple or complex".

\subsection{Furniture and Furnishings}

Changing standards in furniture and interior design require us to respond in ways we deem appropriate. Obviously resource constraints mean we must plan well and base that planning on documented trends. New demands for comfort and sociability are resulting in very different approaches to the traditional library. Hard seating, study carrels and formal seating arrangements have given way to communal spaces where students and readers can work together from the comfort of soft covered seating at round or low tables.

Users may have a choice between an individual desk for private study or research or a group setting where the focus may not be on discussion but simply the feeling of having the company of one's friends or colleagues as one works. In Melbourne, for example, thousands of tertiary students live in tiny apartments without study 
facilities. Thus they choose to work in the congenial and more spacious surroundings of many libraries.

On the other hand, the scholar or researcher needs privacy, quiet and the space to use a wide variety or number of materials, both physical and digital. Our role as librarians is to provide the most appropriate conditions through the means at our disposal. It may well mean that we need to go beyond our library's walls and seek those means. I will draw on my own particular experience to illustrate this point.

\subsection{Recent examples from my own experience}

\section{- National Library of Papua New Guinea}

I now want to discuss a library in great need that is currently being upgraded through major re-furbishment of its buildings and services and to talk about it just a little. When I retired, I did not really anticipate that I would be called on to build on my work by helping others achieve upgraded Library facilities and services.

In 2005 I was engaged through AusAid to conduct the library services component of a scoping study designed to inform the Australian Government of the extent of need within the National Library of Papua New Guinea for a renovation of its building and services.

The Scoping Study was also to set out a costed plan of work whereby the Library could more properly fulfill its role as a National Library for the people of PNG. My role was as the designated library specialist working alongside the selected architects Alexander and Lloyd Pty Ltd whose primary work is in developing countries, especially around the Pacific. For this project their prime and overarching role was defining and costing the scope of required works.
In remarkably quick time, in response to our work, our Prime Minister and the Minister for Foreign Affairs announced that through AusAid the Australian Government would, on behalf of its people, give the people of PNG a renovated and upgraded National Library with enhanced services. This gift was to mark PNG's 30 years of independence.

So, in 2006 , I was invited by those same Sydney-based architects, to become part of their tender bid to undertake the required work as it was to be tendered. We won the tender and right now that library is being thoroughly upgraded. It is due to open in September this year.

The seemingly hopeless conditions for collection preservation, storage and processing together with backlogs of all kinds and the general condition of much of the building whose air-conditioning does not function, whose roof leaks and which is inadequately secured against theft and break-ins is at last being rectified.

The tragedy is that the available funds preclude the purchase of the chosen library management and information system Ex Libris which the PNG staff worked so hard with colleagues from Australia to specify and finally select. Its absence will, in my view, seriously jeopardize its role as a truly National Library. I have been called on to assist with the politicking this requires at many levels but so far without success. We have not given up hope.

With completion of this upgrade, notwithstanding the temporary absence of a library information and management system, the people of Papua New Guinea will again look with pride on what will once more be recognized as a national asset, representing in its collections and specialist services the documentary record of their nation as well as a means of sharing 
it with, looking to and learning from the world beyond.

\section{- Ormond College, University of Melbourne}

Similarly, early in 2006, Chris Awcock and I were engaged to advise the Master of Ormond College here at the University of Melbourne to prepare a series of recommended strategies for the further development of the Ormond College Library. Our report was widely accepted within the college and planning is well under way, as well as fund raising strategies to ensure its eventuality.

From this brief round-up you can see that libraries as buildings have pre-occupied me for much of my career but I always remind myself that it is people for whom they are intended. Their purpose is not as built monuments to the government of the day or to ennoble wealthy patrons or to bring glory to the few. Rather it is to provide improved services where people's library experience and use is enhanced through new levels of comfort and an aesthetically pleasing physical environment, made possible through judicious planning and building.

So it is that I have been lucky enough to travel the world studying the latest library buildings, talking to those who planned them and to those in charge of them as well as to many of their users. I have been part of the world of IFLA (the International Federation of Library Associations and Organisations) through committee membership of its Library Buildings and Equipment Section and thus deeply engaged with the world of library architecture.

\section{Technology as enabler and challenge.}

The third of my library essentials for effective practice is technology as an enabler and as a challenge. Earlier in this presentation I said 1987 was a marker. In 1987 the SLV was only then about to acquire its first library and information management system. It is now in at least its third version. A major focus of the State Library of Victoria today in 2007 is on Estrategy and creating the $21^{\text {st }}$ century library.

When I addressed this conference in 1987, the internet for all but the few specialists had barely been conceived let alone become the worldwide phenomenon it is today. Neither in 1987 had animation reached its current apotheosis. Now brilliant animators produce the likes of Toy Story, Cars, a Bug's Life, Happy Feet, etc. In 2002 when I retired from full-time employment, blogs, podcasts, ipods, Playstation, YouTube, Myspace and now Facebook either did not exist or were in their most elementary form.

Increasingly our library users expect to be able to find and use all of them in their libraries because they can certainly use them at home or at work or university. You only have to look at any campus to see laptops being used wherever people gather, even sitting on the grass but utilizing the wonders of the wireless world. Although online networks were widespread in the 1980s, with WANS and LANS being much heralded, now they have become commonplace. Networking as a major means of social and professional discourse is in our common parlance. Our talk now is of "virtual networks." Wireless technology has become the norm, giving ultimate flexibility and offering new levels of access to the online world.

The State Library of Victoria in its Experimedia space signals the importance of embracing new technologies in the wider interests of its users. It also challenges the traditional approach to and purpose of a library. Its facilities include a large screen where moving and still images are projected; it includes too a computer games pod and virtual reality facilities for its users. 
It is furnished in complete contrast to the rest of the Library and is intended to challenge, to inform and to entertain.

Our library users expect us to make all these technologies available to them both within the library itself and as they carry their wireless laptops from place to place.

What is happening with all this technology?

In beginning my research for this three weeks ago, I Googled "library blogs" and in .8 of a second I learned that there were 133 million library blog citations at that moment. That indicates the nature of our professional challenge. How can those uninitiated in the techniques of searching bring order out of such chaos, or draw meaning from what is found and in timeefficient ways? By the way, did you know that "blog" and "Google" have been given lexicographic authenticity by their inclusion in the Oxford English Dictionary? In looking for photographs to illustrate some of my points, I came across many photos on blogs created by travelers, readers, library visitors and the like. It reminded me of an article by Thomas Friedman that I had just read in the Saturday Age, syndicated by the New York Times. He says

When everyone has a blog, a MySpace page or a Facebook entry, everyone is a publisher. When everyone has a cell phone with a camera in it, everyone is a paparazzo. When everyone can upload a video on You-Tube, everyone is a film maker, everyone else is a public figure. We're all public figures now. The blogosphere has made the global discussion much richer - and each of us so much more transparent.

Friedman, in that article quoted from a recent book by Dov Seidman called How. Seidman's thesis is that in this transparent world "how" you live your life and "how" you conduct your business matters now more than ever because people can see into what you do as well as tell others about it. Whereas once we made mistakes, sometimes covered them up and hoped people would not remember them, now "the persistence of memory makes second chances harder to come by". ...In the information age, life has no chapters or closets; you can leave nothing behind, and you have nowhere to hide your skeletons....for this generation, much of what they do, say or write will be preserved online forever. Before employers even read their resumes, they'll Google them.

We need to ensure our contemporary world is shaped not only by the wisdom of past ages but also by the new learning the future will unfold.

How well is your theological library doing in the face of these challenges and opportunities for new forms of library service?

\section{Financial, corporate and philanthropic support}

The fourth of my library essentials is financial, corporate and philanthropic support.

Much of my work for libraries in both South Australia and Victoria has been outside the traditional world of librarianship with its focus on readers and users. It has in fact been focused on trying to win friends and influence people in high places - decision makers and those within the corporate world and in philanthropic circles. This is because as librarians and information specialists we have failed to have any significant impact on those whose financial resources and wide networks of people across the world could be used to our advantage.

Either our world is closed to them through lack of our perceived relevance or we have not been adept enough at moving out beyond our familiar library territory into 
theirs where dialogue between us might result in enhanced understanding of each other's needs. We as a profession need to be able to demonstrate our unique offering and capability and not wait for "someone to turn up and ask us for something" as The Bulletin advised its readers all those years ago.

The State Library of Victoria was, in 1987 , totally neglected by the Government of the day and had been for most of the $20^{\text {th }}$ century. Today it is highly regarded and well supported by Government although no public funding is ever enough. A considerable means of additional support for the SLV comes increasingly through private philanthropy, wills, bequests and the SLV Foundation.

Any visitor today to the State Library of Victoria, for example, will see how important, even critical, philanthropic and corporate resources have been in terms of the Library's redevelopment program.

There is the Keith Murdoch Gallery, the Cowen Gallery, the Helen MacPherson Smith Genealogy Centre, the Herald and Weekly Times Newspaper Reading Room - each named in acknowledgement of personal, family, philanthropic or corporate generosity. While government has funded the building works and much of the refurbishment, it is money from those other sources which has:

- added immeasurably not only to the Library's financial resources

- enhanced its image in the wider community

- won it recognition within the corporate and philanthropic sectors as an enterprise it might otherwise have overlooked

- widened the range of individual men and women, boys and girls who now use the State Library in ways that once were but a dream.

It was my good fortune to have been challenged to identify those who would support the State Libraries of South Australia and Victoria through their donation and corporate support and to be a part of all those who made the dream become reality. Today's varied and extensive public programs of both those libraries and especially the State Library of Victoria with its

- continuing financial and moral support from government -including funding for the proposed Centre for the Book,

- the State Library Foundation's growth and commitment,

- the extensive technological underpinnings and support

- the weight of visitor and user numbers are all testament to the Library's relevance and importance in a changing and challenging world.

Your own theological libraries may be vastly different in scale and major purpose yet 1 am sure your challenge is the same "winning friends and influencing people in high places" as I call it. Those high places may be your university's central administration, your church hierarchy or your college council or even your Library committee. Or they may be among your college or university alumni - individuals whose life and work has been enriched long ago or recently through use of your library's collections and services. On the other hand those you need to influence may be altogether outside your more familiar terrain.

This means you need to find a common link but whoever they are, you need them if you wish to extend your support base and add to your library capability. Your challenge is to find them. Inevitably your own funding base is insufficient to enable you to live the dream. What is it that holds you back from achieving all you hope for in your library and know you could do if you had the means? Where should you start?

First, set your priorities, second develop two or three key goals, third, win support 
for them among your colleagues and users, then from your relevant authority, fourth identify the most likely sources of support and fifth, using the network of support you have thus built - even if it is small - make those critical first contacts and with any appointments or meetings you have make your case for support. This is not easy and you will not always succeed. But when you do, you will be well on your way to extending your support base. My own experience confirms for me the old adage "success breeds success".

Having delineated my four essentials of library practice - a philosophical base, appropriate buildings, enabling technologies and financial support - I now make some final comments.

\section{Concluding comments}

The prayer I quoted at the beginning gives thanks for "the gift of language and the written word". It also seems to reflect the importance of words as the means of human expression and of our ability to communicate with one another.

I began that 1987 paper with the following words:

"In the beginning was the Word..."

"I am Alpha \& Omega, the beginning and the end, the first and the last."

Without disrespect to any for whom those words are rich in Christian symbolism and for whom those same words convey an eternal truth, they seem to me to act as a reminder that language as spoken or as written will continue to be the basis of our profession as librarians and as information specialists. Without written language, even from its beginnings as pictogram and hieroglyph, the notion of books and libraries and librarians would not exist.

Can you imagine a world where there was no record of mankind's origins and of his past? From the primitive drawings in the caves at Lascaux or on rocks in the Kakadu National Park to the microchip that has revolutionised the information industry, mankind's innate drive to record and to communicate is living testimony to the power of the word. It was so from man's early beginnings and will surely continue so until the end. Whatever of today is rendered obsolete in the future, human beings will continue to express themselves through language in all its forms and others will seek to learn from such expression.

Even the Bulletin writer knew that his readers in 1917 could expect a response from the notional "librarian" in her "pinnie". He understood that communication was fundamental not only to the person but to the role of the library. Regardless of whatever technologies have been or will be developed, there will always be written and spoken language. Technological advances already have meant that we are able to communicate on a global scale not foreseen even twenty years ago by most of us. The future is in our hands so to create the one we want for our libraries we need to harness the very best ideas, resources and people we can.

I like Winston Churchill's observation:

The empires of the future are the empires of the mind.

Whatever that future brings for our libraries in all their diversity, I conclude with two photographs. Their subject has been my motivating purpose throughout my career. For they speak of hope for a future in which the children of today are enriched through their reading and learning, some of it through our work as librarians. These children, vastly different in ethnicity, culture, way of life and material goods will still, through their young minds, dream of their own future that some of us will be lucky enough to have influenced - even for moment. 